\title{
Fuel Cell Electric Vehicle Performance Composite Data Products: Spring 2018
}

Jennifer Kurtz, Sam Sprik, Chris Ainscough, Genevieve Saur, and Shaun Onorato May 2018 


\section{Analysis Categories}

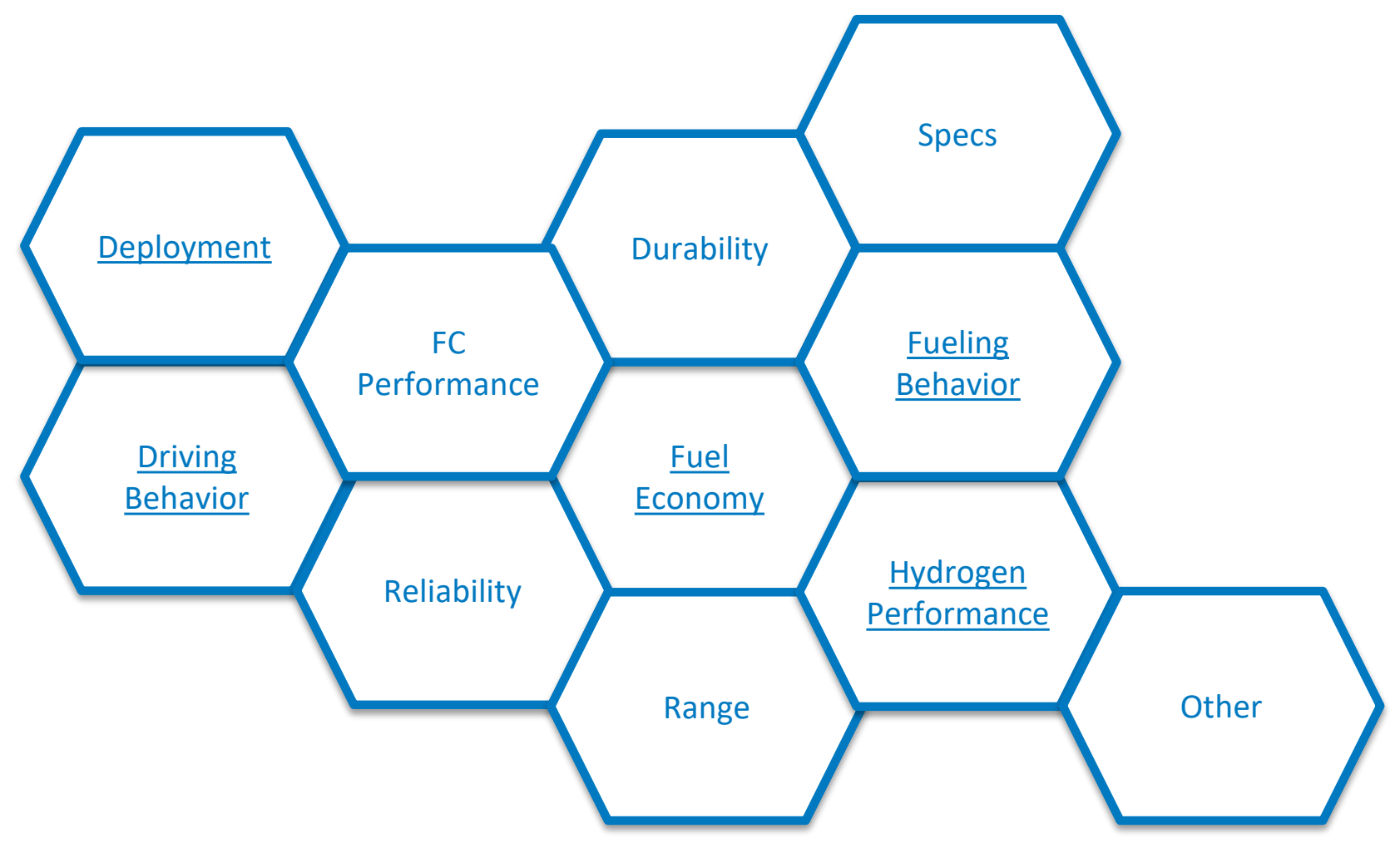




\section{CDP-FCEV-175: Summary of Key FCEV Metrics}

\section{Summary of Key FCEV Metrics}

\begin{tabular}{|c|c|c|c|c|c|}
\hline Vehicle Performance Metrics & $\begin{array}{l}\text { DOE Target } \\
(\text { Year 2020) }\end{array}$ & LD3 $^{b}$ & LD2+ ${ }^{\mathrm{c}}$ & LD2 $^{\mathrm{C}}$ & LD1 $^{c}$ \\
\hline Max Fuel Cell Durability Projections (hours) & 5,000 & 4,130 & -- & 2,521 & 1,807 \\
\hline Average Fuel Cell Durability Projection (hours) & & 2,442 & 1,748 & 1,062 & 821 \\
\hline Max Fuel Cell Operation (hours) & & 5,648 & 1,582 & 1,261 & 2,375 \\
\hline Adjusted Dyno (Window Sticker) Range (miles) & & $200-320$ & -- & $196-254$ & $103-190$ \\
\hline Median On-Road Distance Between Fuelings (miles) & & 124 & 98 & 81 & 56 \\
\hline Fuel Economy (Window Sticker) (mi/kg) & & 53 (median) & -- & $43-58$ & $42-57$ \\
\hline Fuel Cell System Efficiency at 1/4 Power & 65 & $57 \%$ (average) & -- & $53 \%-59 \%$ & $51 \%-58 \%$ \\
\hline Fuel Cell System Efficiency at Full Power & & $43 \%$ (average) & -- & $42 \%-53 \%$ & $30 \%-54 \%$ \\
\hline Specific Power (W/kg) & 650 & $240-563$ & & $306-406$ & $183-323$ \\
\hline Power Density (W/L) & 650 & $278-619$ & & $300-400$ & $300-400$ \\
\hline \multirow{2}{*}{$\begin{array}{l}\text { System Gravimetric Capacity (kg H2/kg system) } \\
\text { System Volumetric Capacity (kg H2/L system) }\end{array}$} & $5.5 \%$ & $2.5 \%-3.7 \%$ & & $2.5 \%-4.4 \%$ & \\
\hline & 0.04 & $0.018-0.054$ & & $0.018-0.025$ & \\
\hline
\end{tabular}

a. Fuel Cell Technolgies Office Multi-Year Research, Development, and Demonstration Plan

(https://energy.gov/eere/fuelcells/downloads/fuel-cell-technologies-office-multi-year-research-development-and-22)

b. Current results are available at http://www.nrel.gov/hydrogen/proj_fc vehicle evaluation.html (Updated 5/2017)

c. National Fuel Cell Vehicle Learning Demonstration Final Report (http://www.nrel.gov/hydrogen/pdfs/54860.pdf) 

Targets

\section{Summary of Key FCEV Metrics vs DOE Targets ${ }^{a}$}

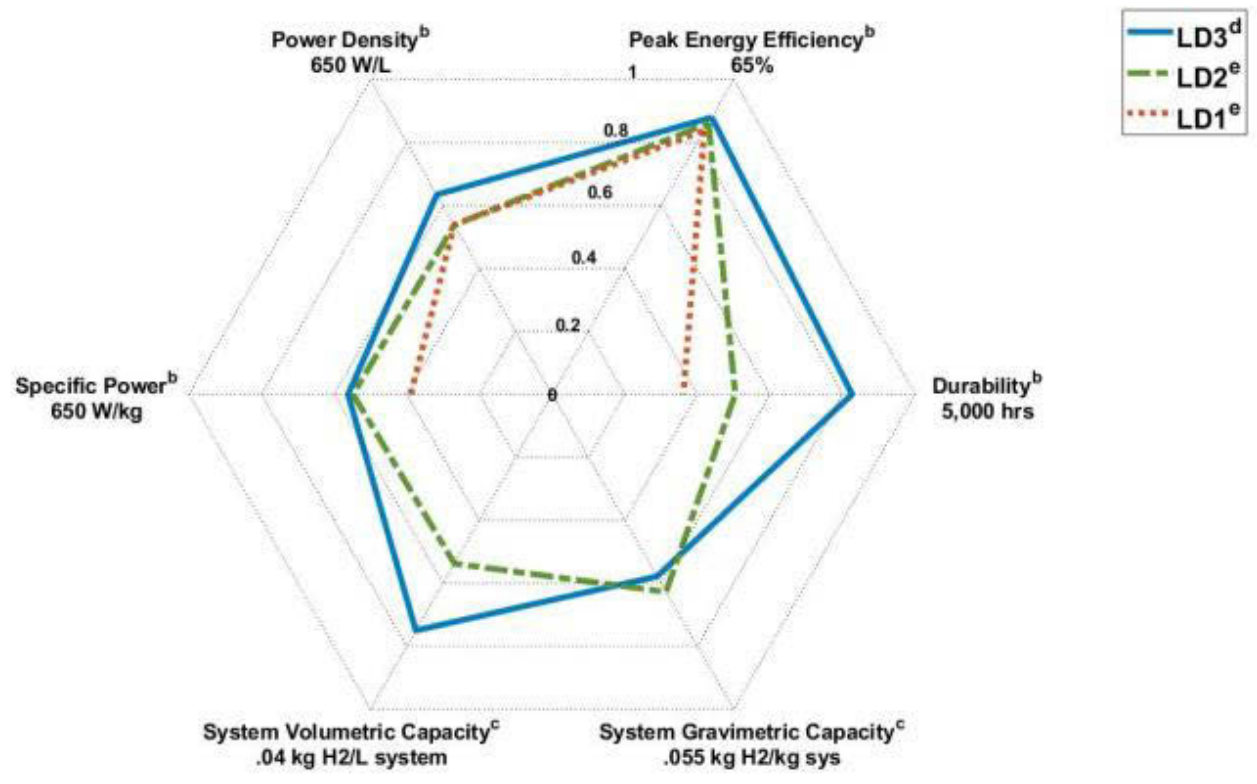

a. Results are a fraction of the 2020 targets in the Fuel Cell Technolgies Office Multi-Year Research, Development, and Demonstration (MYRDD) Plan (https://energy.gov/eere/fuelcells/downloads/fuel-cell-technologies-office-multi-year-research-development-and-22) b. MYRDD Fuel Cell section 3.4 (last updated May 2017), table 3.4.3.

c. MYRDD Hydrogen Storage section 3.3 (last updated May 2015), table 3.3.3

d. Current results are available at http://www.nrel.gov/hydrogen/proj_fc_vehicle_evaluation.html (Updated 4/2018) 
Deployment 


\section{CDP-FCEV-33: FCEV Evaluation Phases, Participants, Publications, and Trip Count}
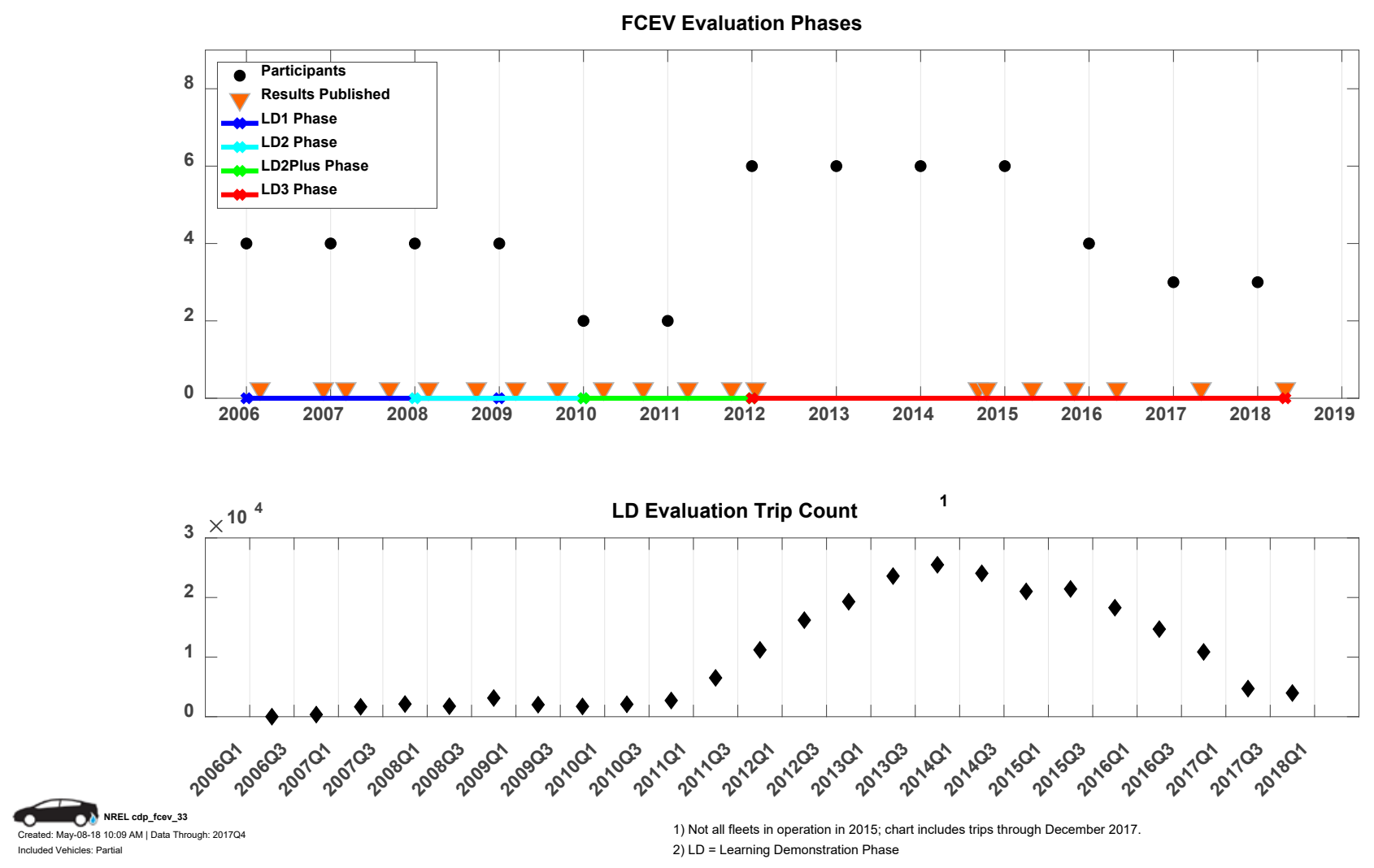


\section{CDP-FCEV-53: FCEV Count and Cumulative Miles}

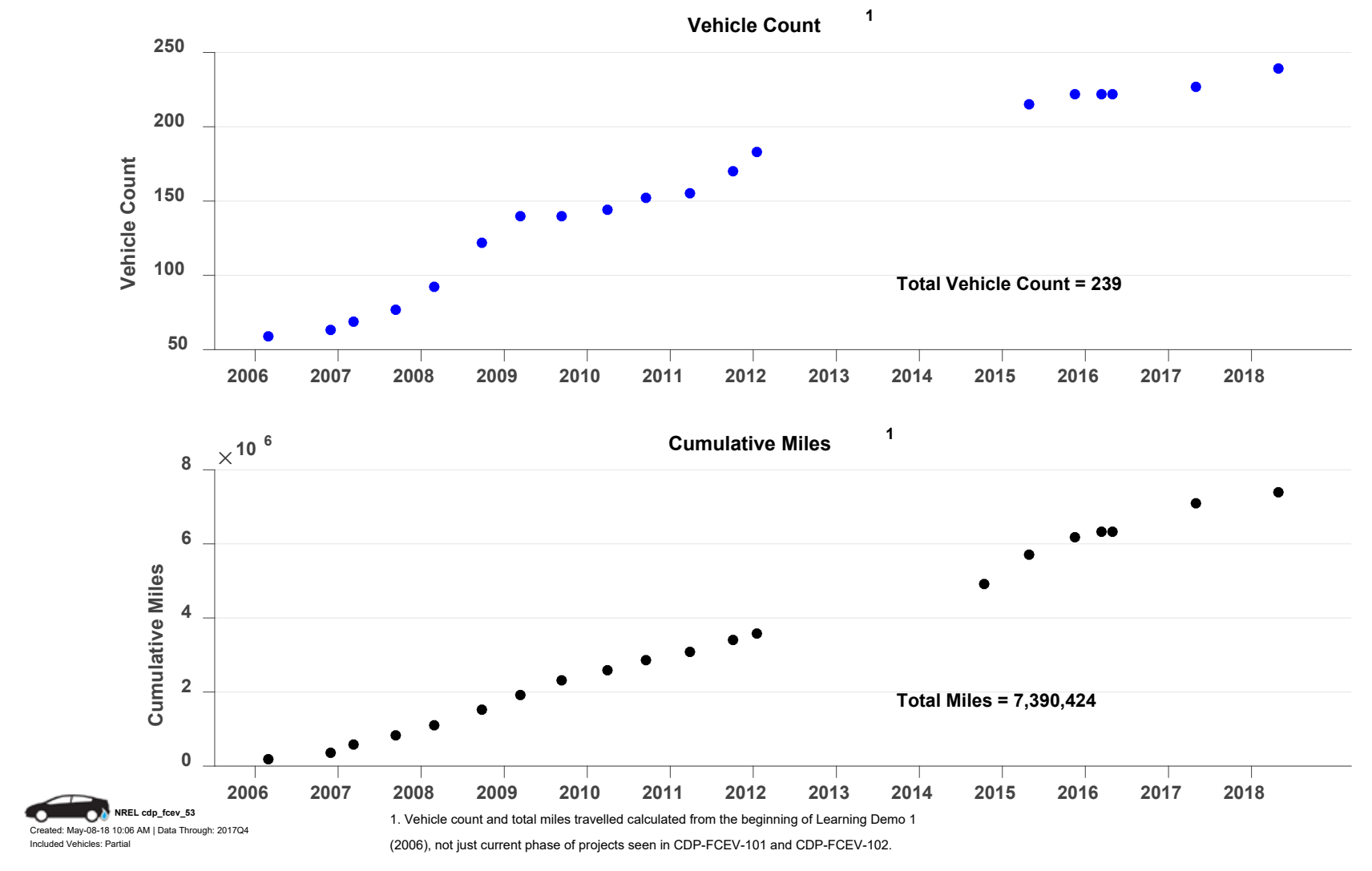




\section{CDP-FCEV-101: Vehicle Count}

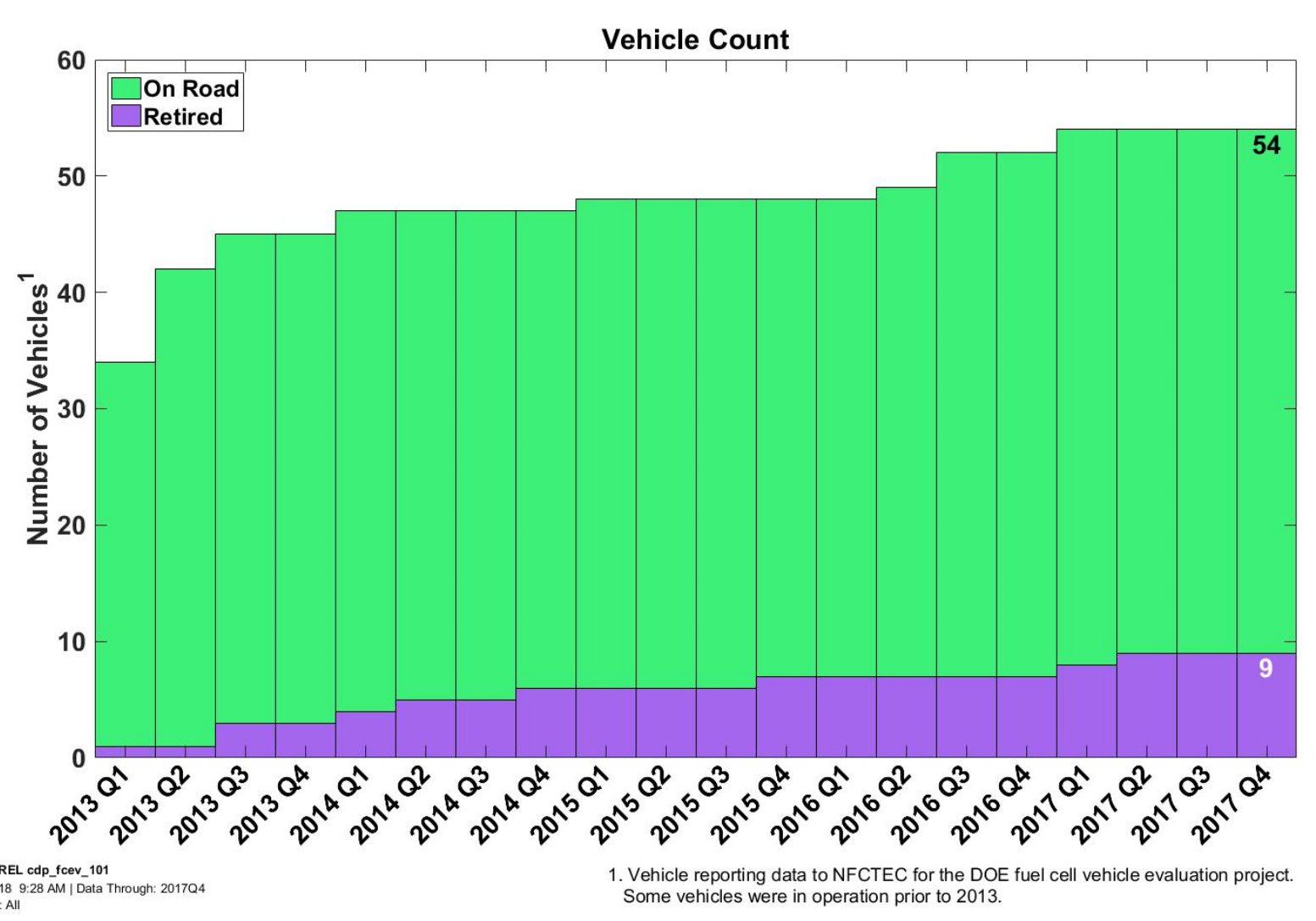


Driving Behavior 


\section{CDP-FCEV-102: Vehicle Miles}

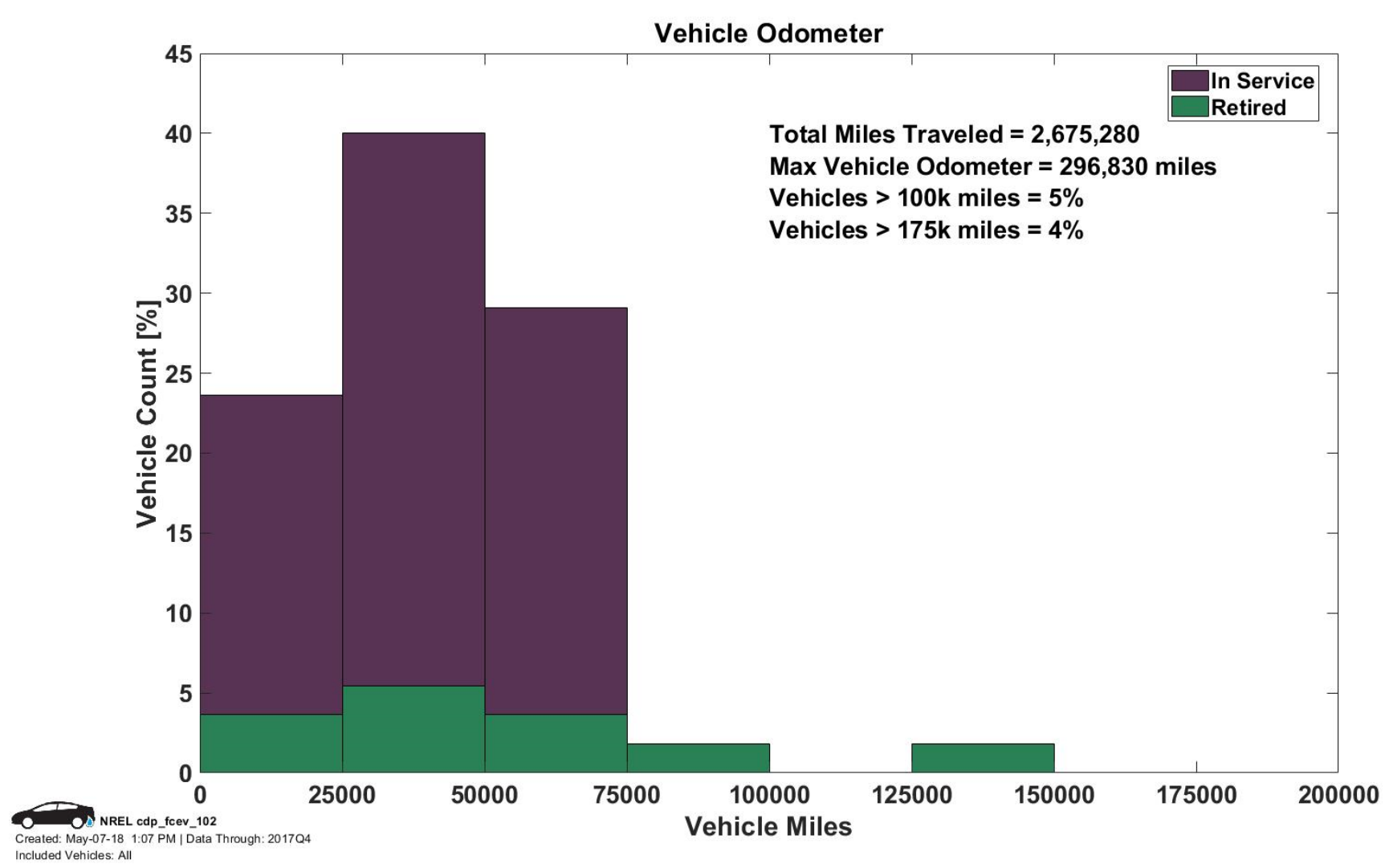




\section{CDP-FCEV-104: Fuel Cell Stack Operation Hours}

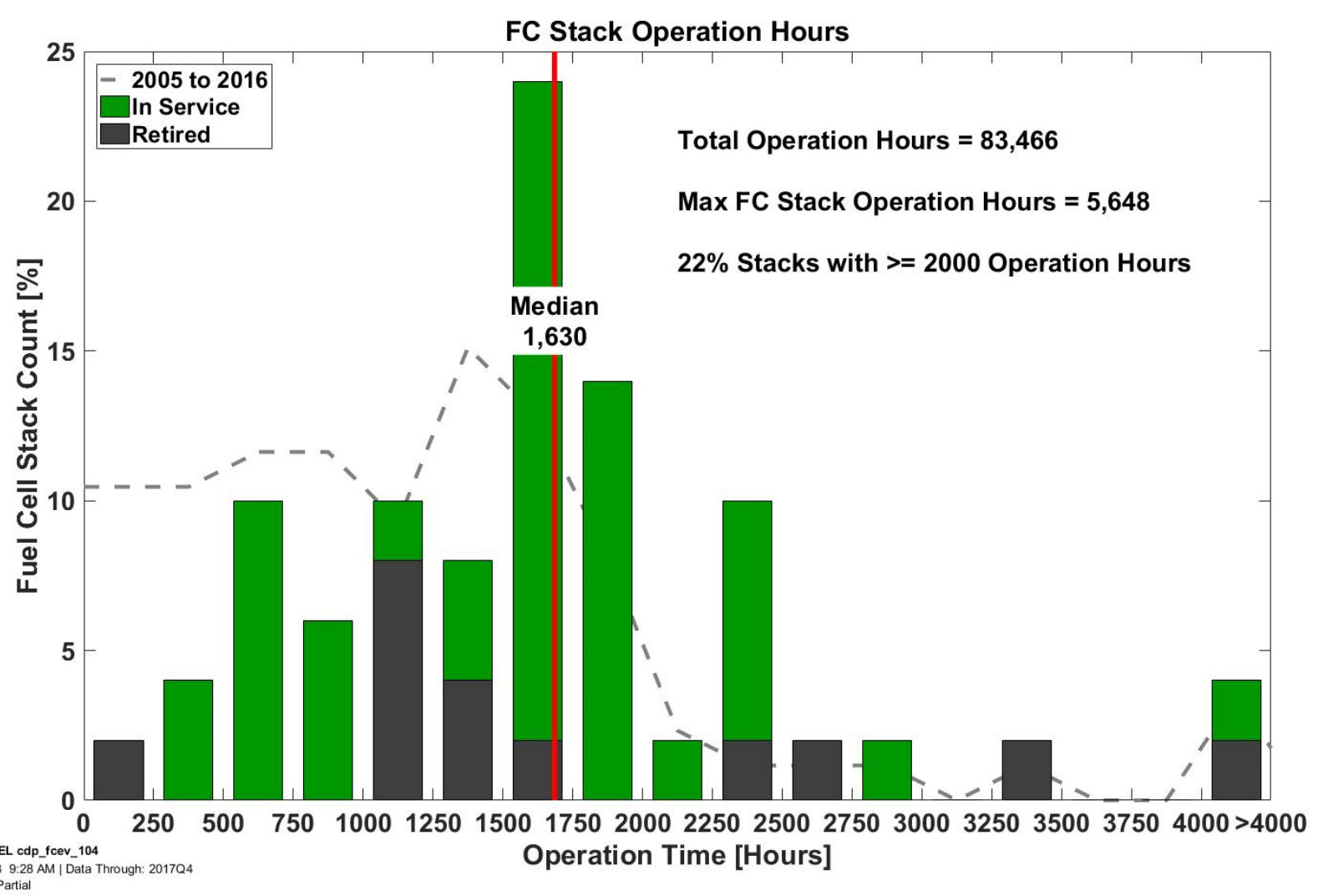




\section{CDP-FCEV-118: Driving Start Time by Time of Day}

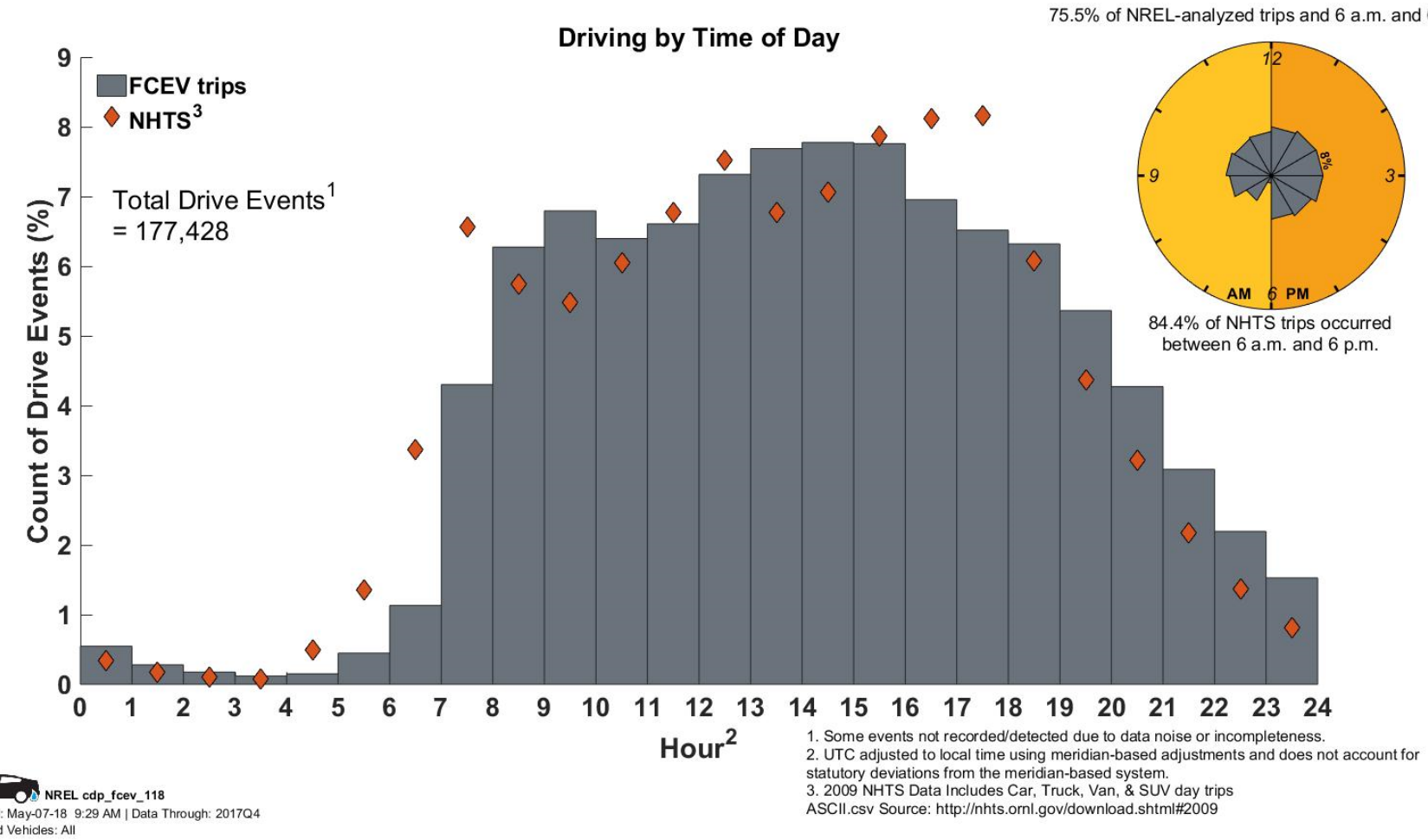




\section{CDP-FCEV-119: Driving by Day of Week}

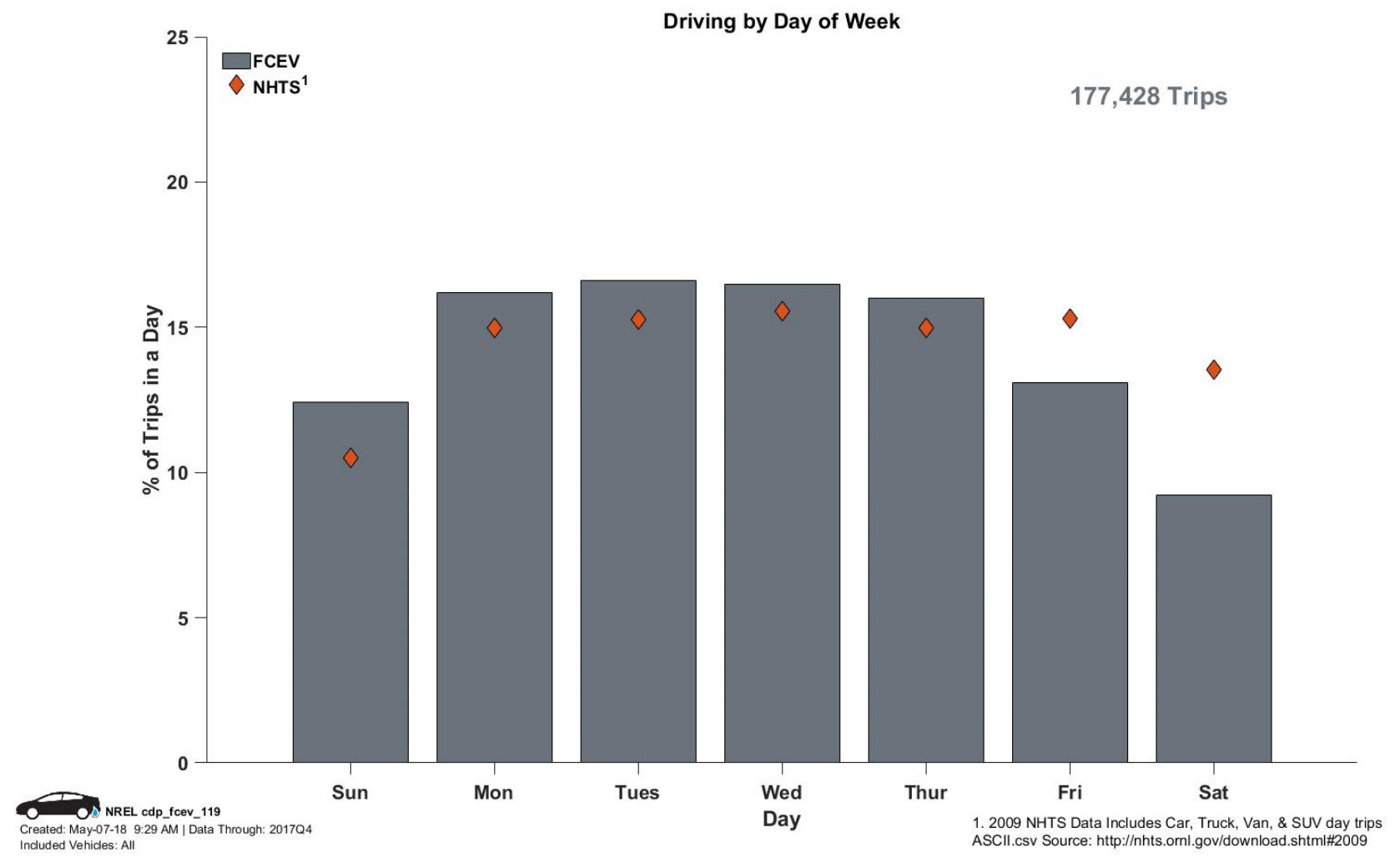




\section{CDP-FCEV-126: Average Trip Speed}

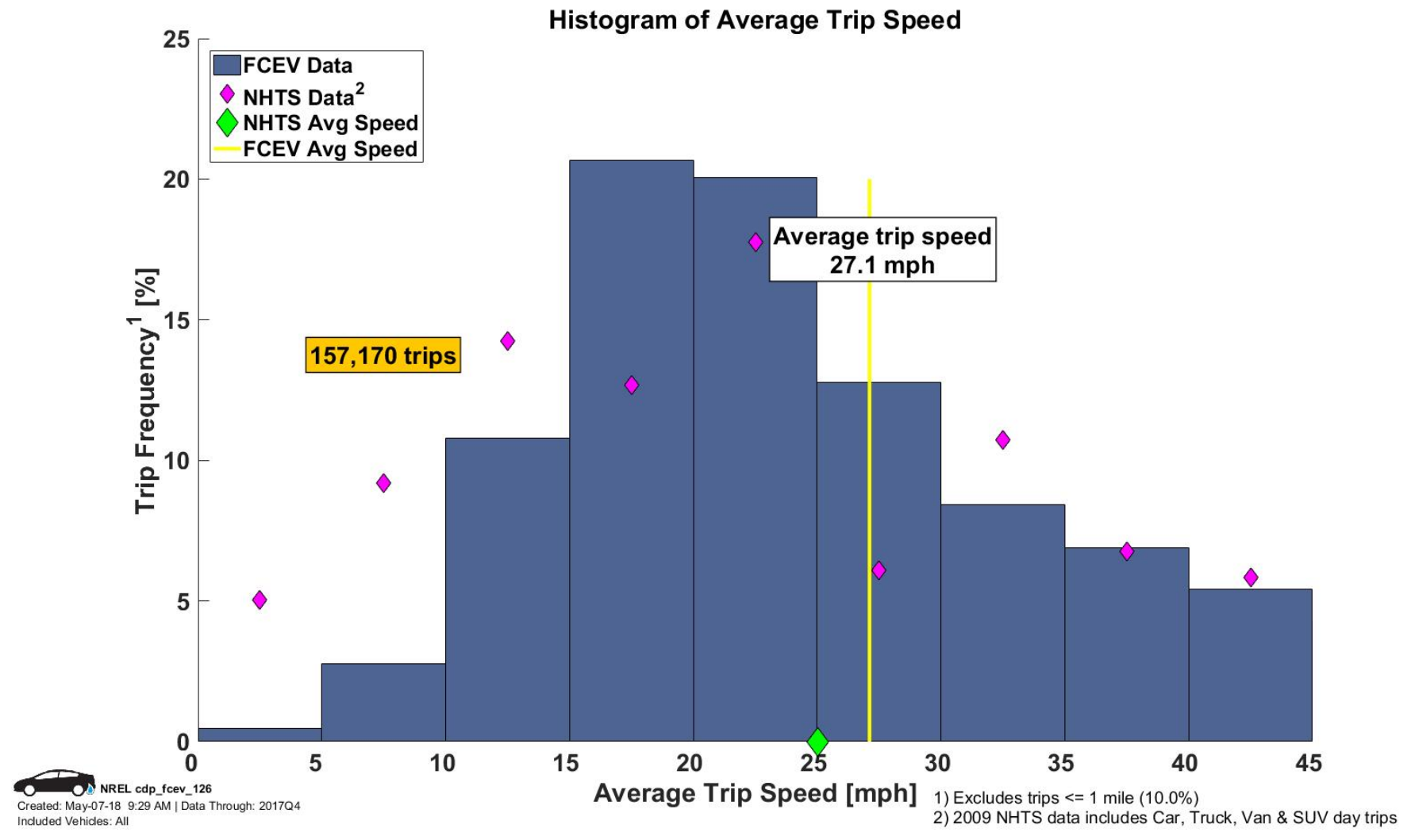


Fuel Economy 


\section{CDP-FCEV-108: Vehicle Fill Amounts}

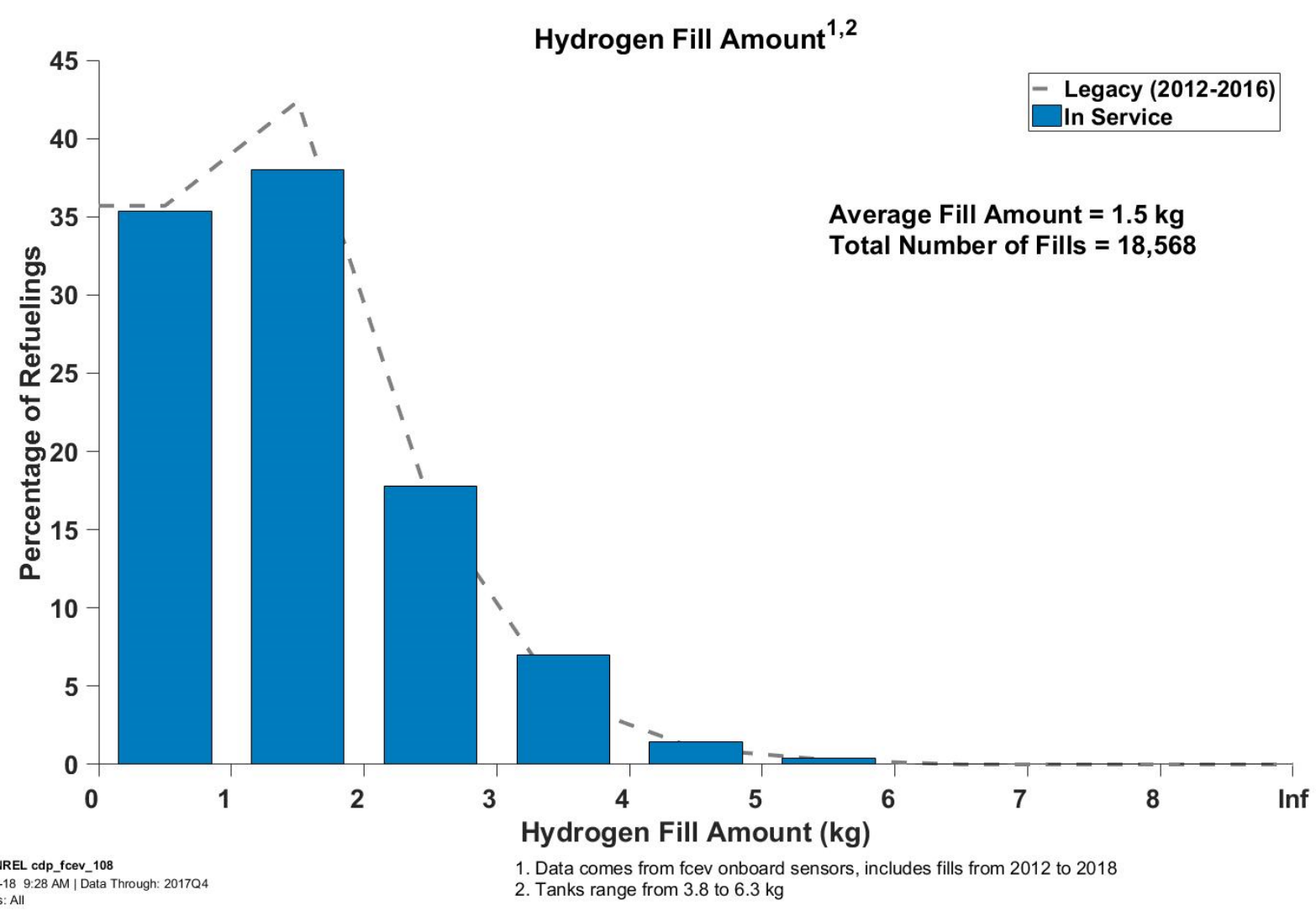




\section{CDP-FCEV-114: Average Vehicle Fuel Economy}

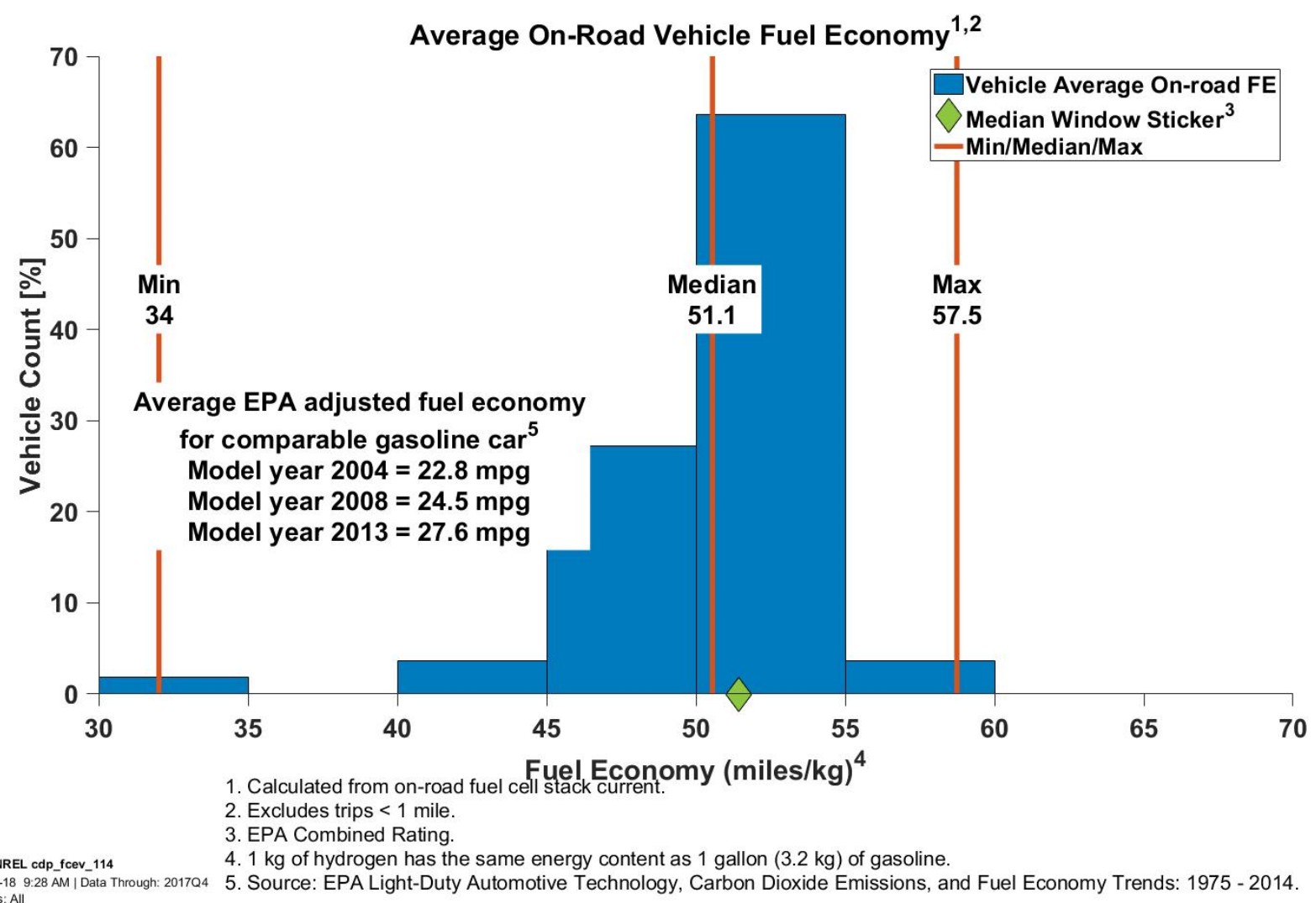



Fuel Economy

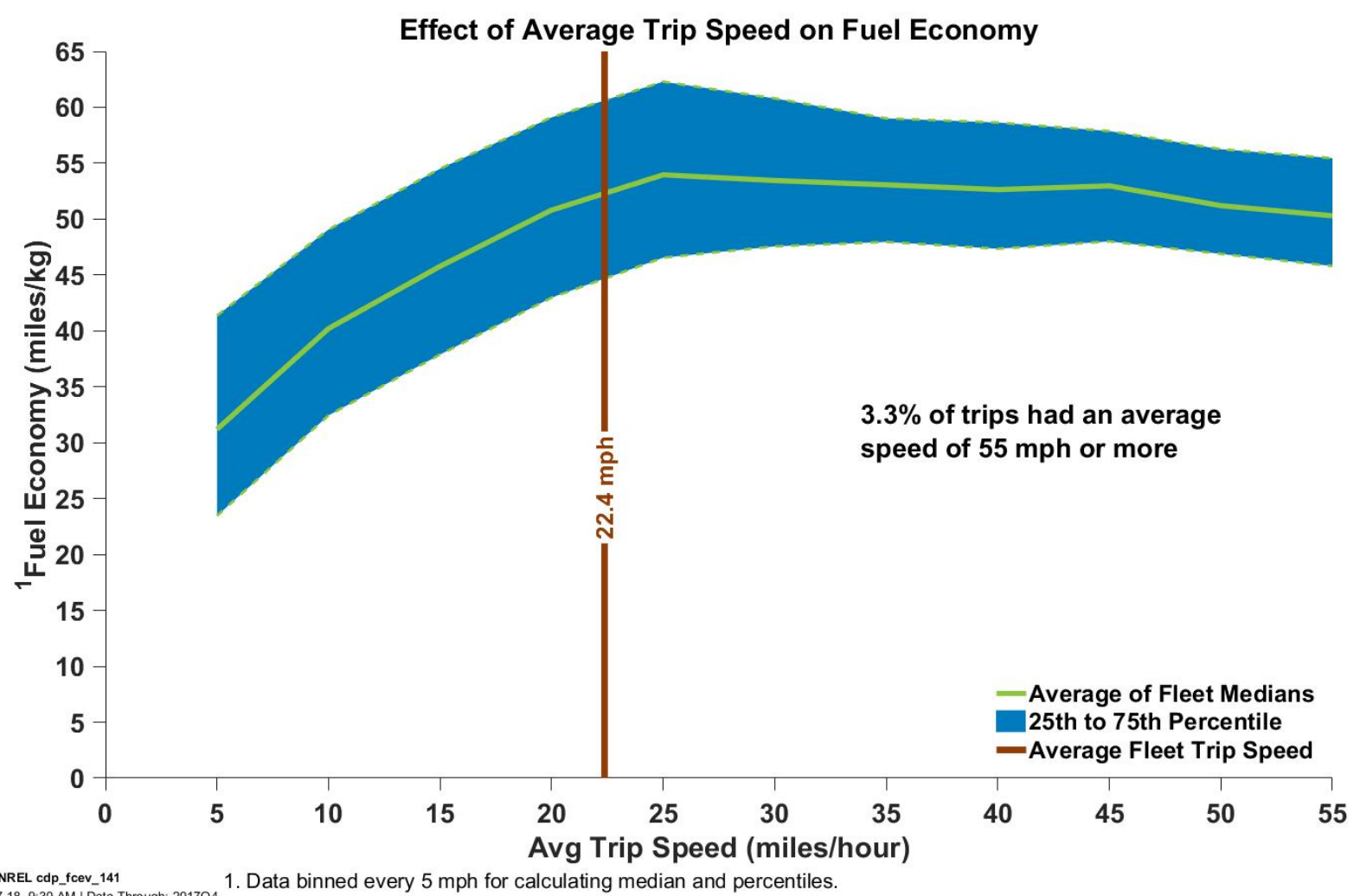




\section{CDP-FCEV-144: Average On-Road Fuel Economy by Vehicle Odometer}

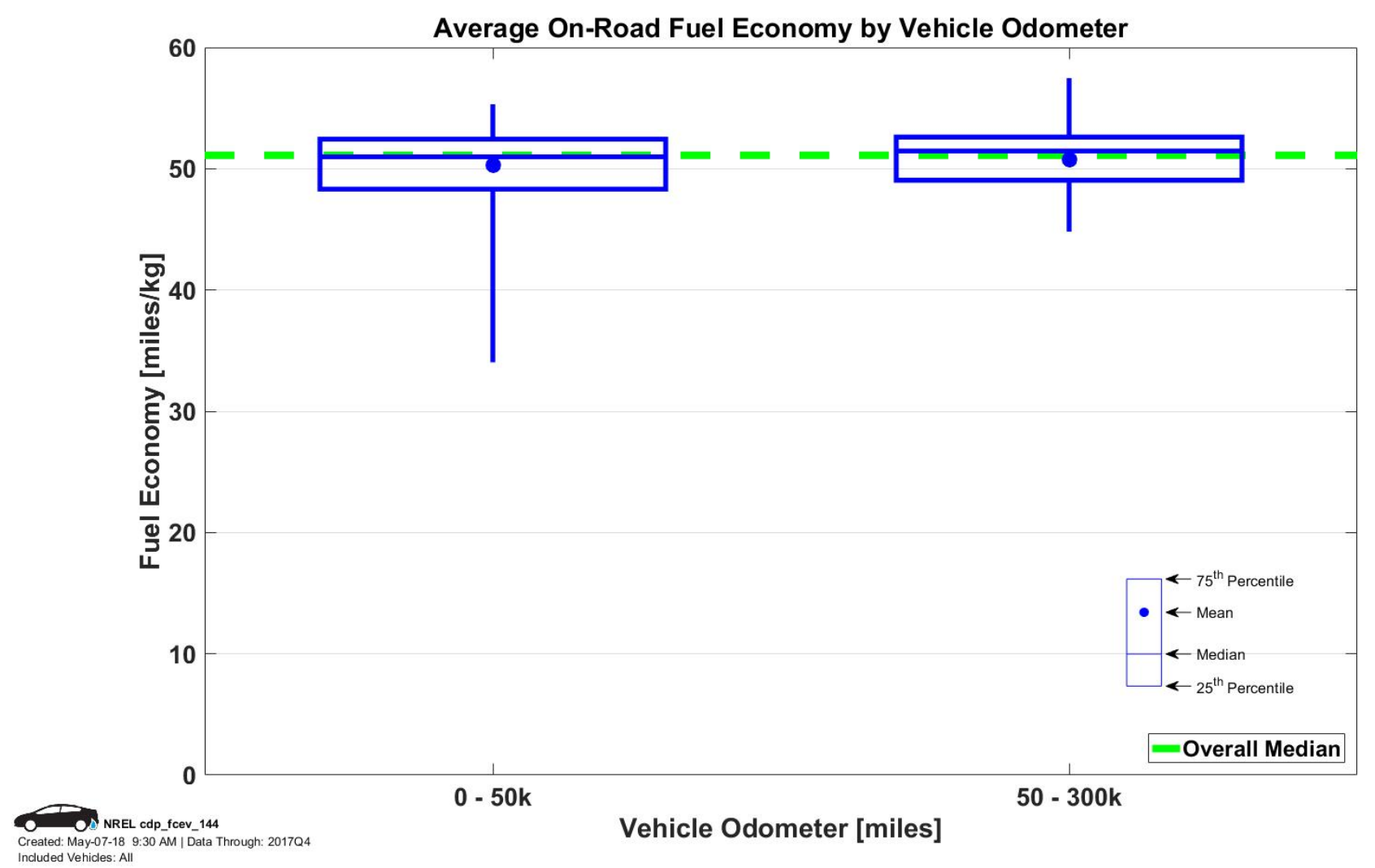




\section{CDP-FCEV-169: GHG Emissions by Fuel Economy}

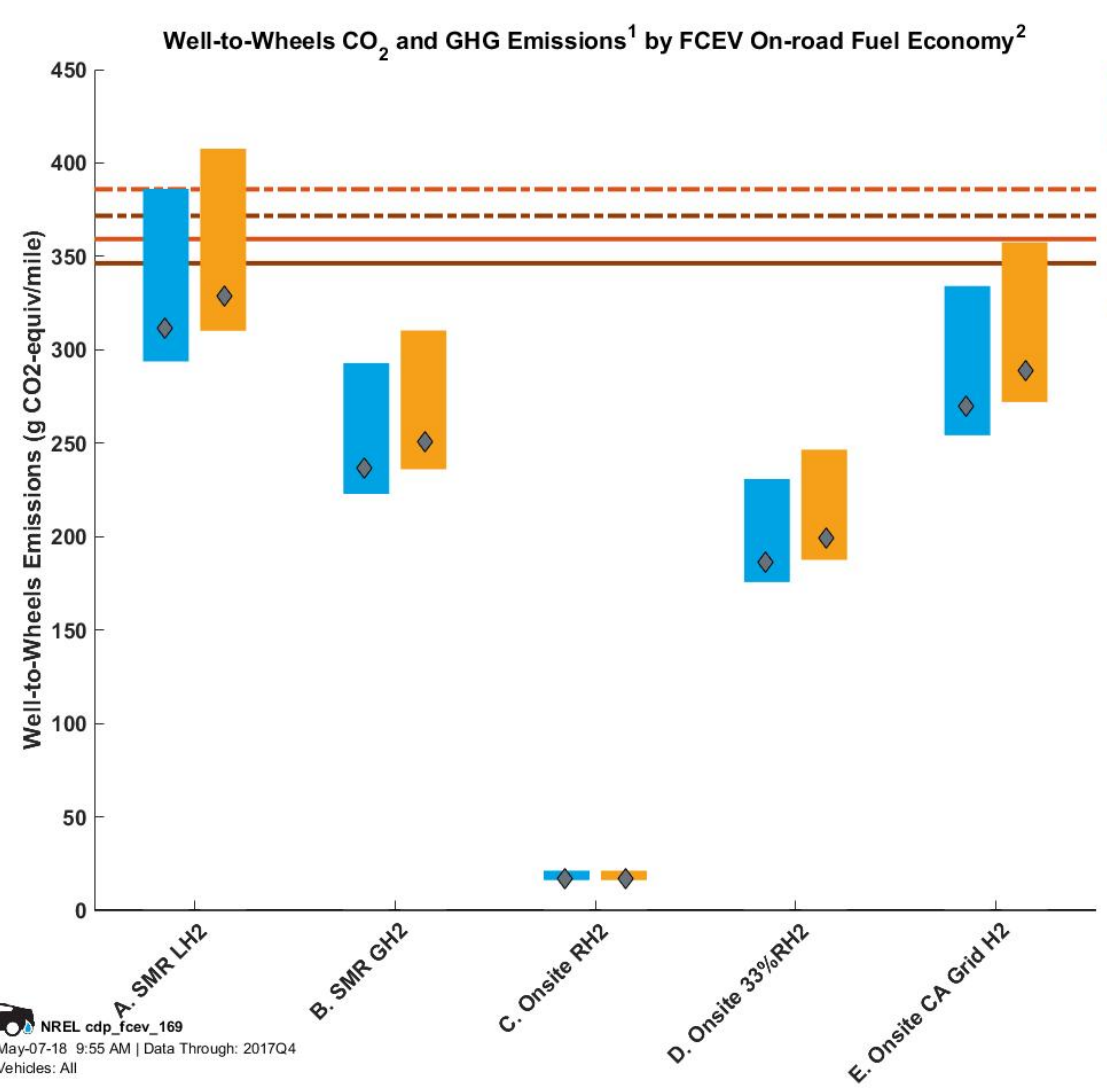

CO2 FCEV Min/Max On-road FE
GHGs ${ }^{4}$ FCEV Min/Max On-road FE

$\checkmark \mathrm{CO} / \mathrm{GHG}$ FCEV Median EPA FE ${ }^{5}$

- CO2 Baseline ${ }^{6}$ Passenger Car - CA Gas

- GHG Baseline ${ }^{6}$ Passenger Car - CA Gas

-- CO2 Baseline ${ }^{6}$ Light Duty Truck - CA Gas

-- GHG Baseline ${ }^{6}$ Light Duty Truck - CA Gas

1. Source: GREET Fuel Cycle (GREET1 2015) <greet.es.anl.gov> using EPA/EIA emissions factors

2. See CDP-FCEV-114: Calculated from on-road fuel cell stack curren

3. On Road fleet avera

FE plus/minus one standard deviation Min 427 ontent as $1 \mathrm{gax} 56.1 \mathrm{miles} / \mathrm{kg} ; 1 \mathrm{~kg}$ of hydrogen has the same energy 4reenhouse Gas inclu) of gasoline. potential of $\mathrm{CH} 4$, N2O, VOC, CO, NOx, Black Carbon, and Organic Carbo 5. Median FCEV EPA Combined Rating 52.9 miles $/ \mathrm{kg}$. mpg and gasoline light duty truck $126.8 \mathrm{mpg}$

Scenario Description

A. FCEV - Central SMR Liquid H2

B. FCEV - Central SMR Gaseous H2

C. FCEV - Onsite Renewable Electrolysis $\mathrm{H} 2$

D. FCEV - Onsite 33\% Renewable Electrolysis H2

E. FCEV - Onsite CA Grid Mix Electrolysis GH2 
Fueling Behavior 


\section{CDP-FCEV-106: Average Calendar Days Between Refueling per Vehicle}

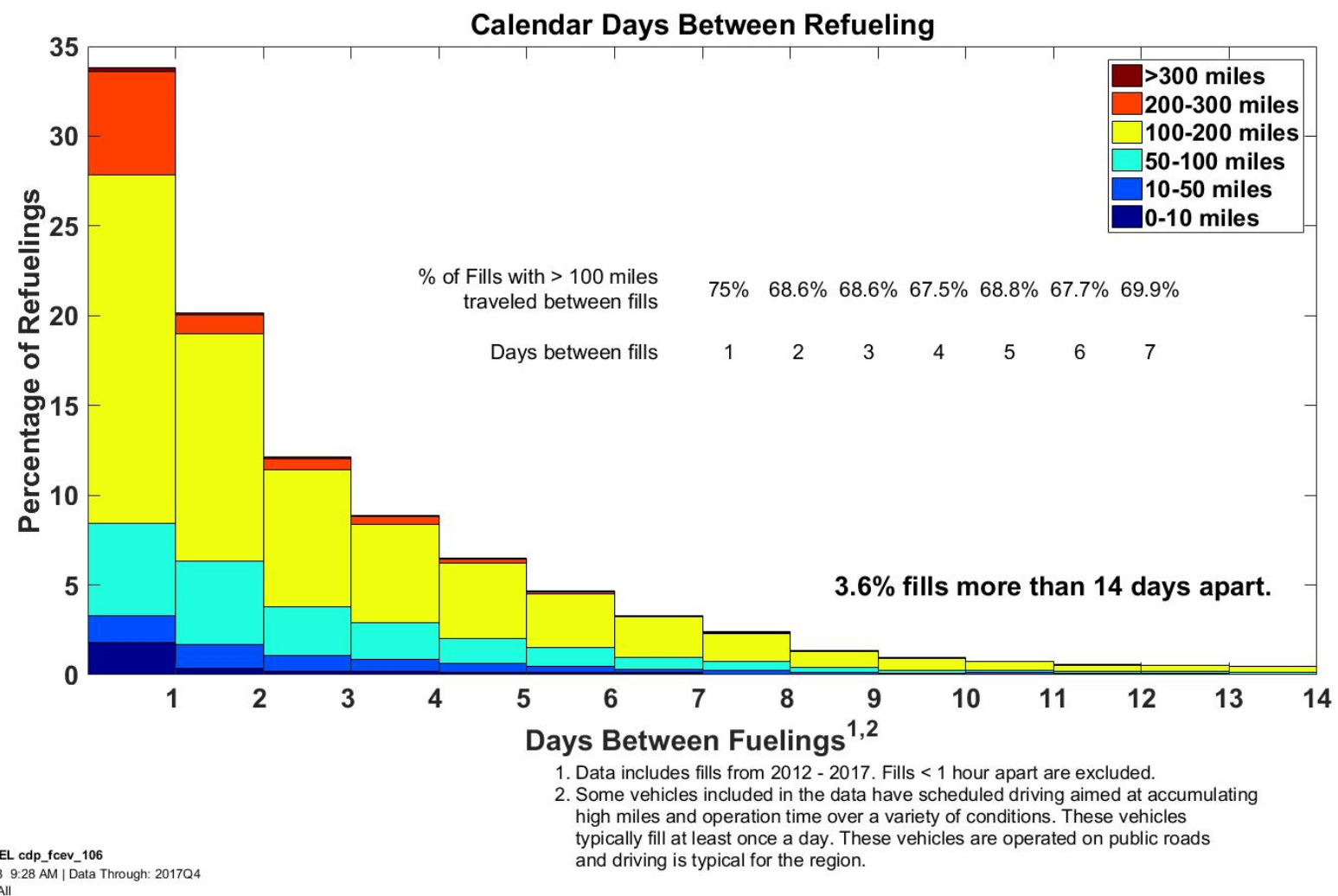




\section{CDP-FCEV-116: Refueling by Time of Day}

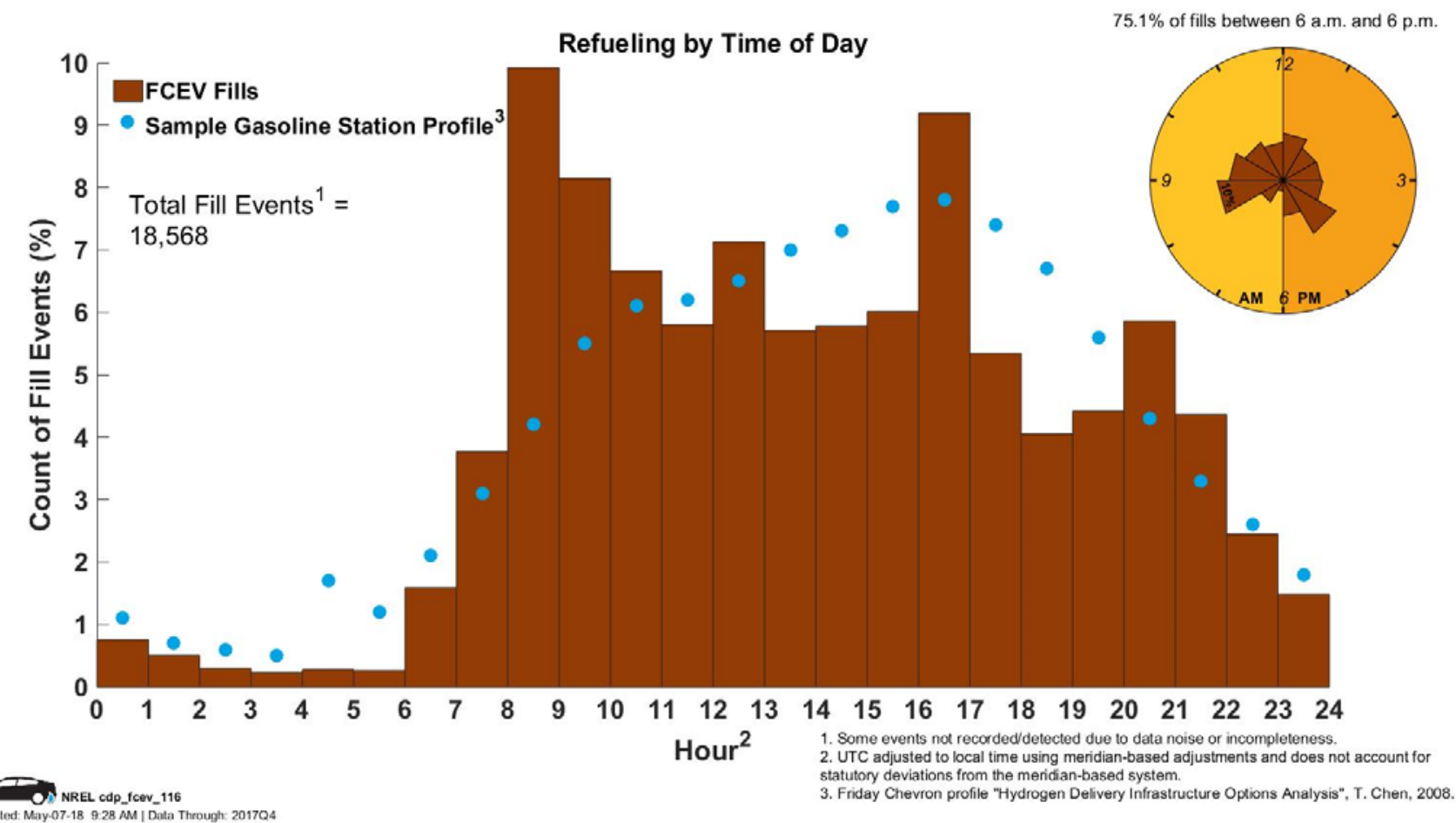




\section{CDP-FCEV-117: Refueling by Day of Week}

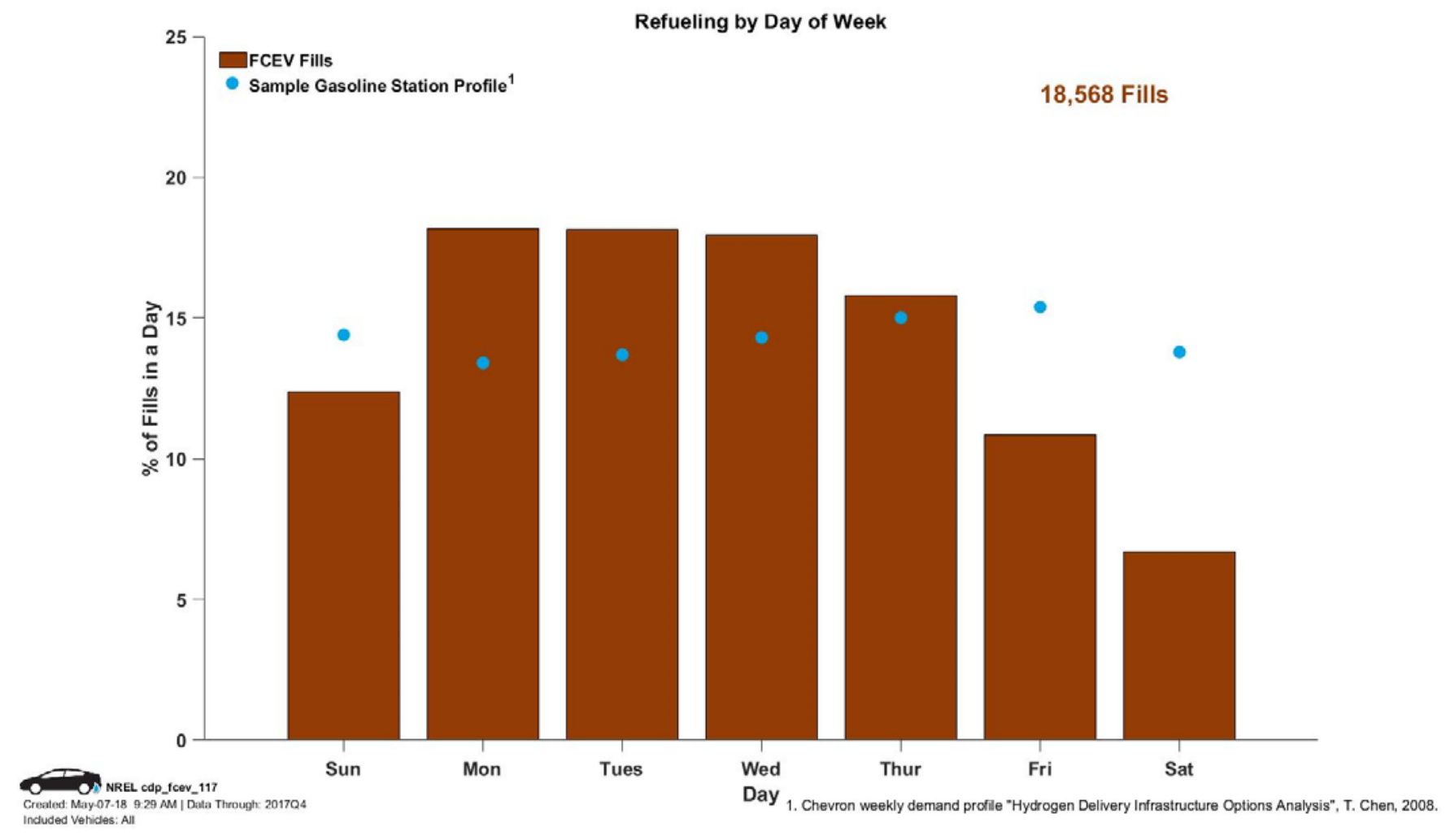




\section{CDP-FCEV-146: Vehicle Tank Temperatures versus Ambient Temperatures}

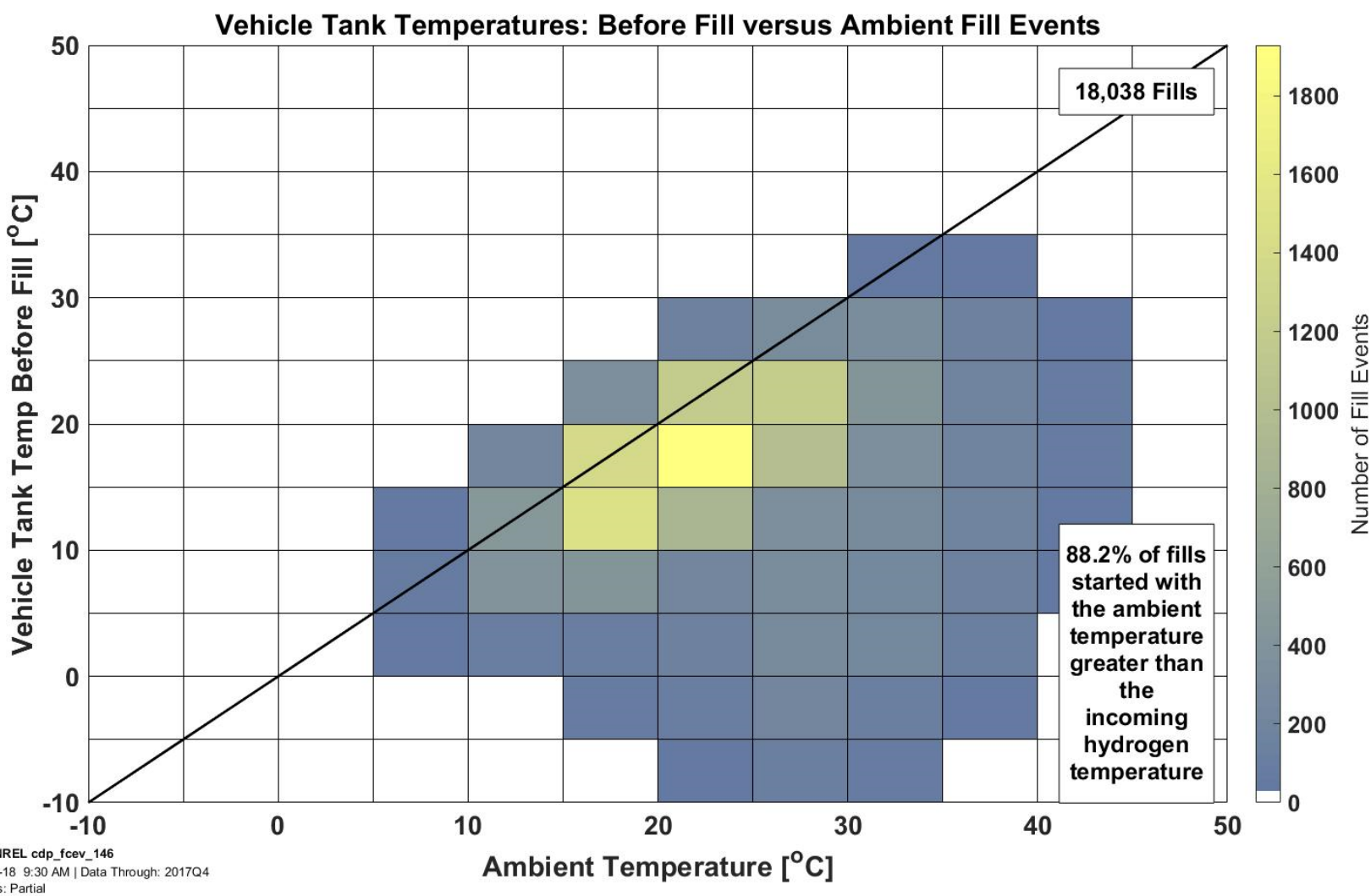


CDP-FCEV-149: Fill Pressure and Temperatures Compared with SAEJ2601 Limits

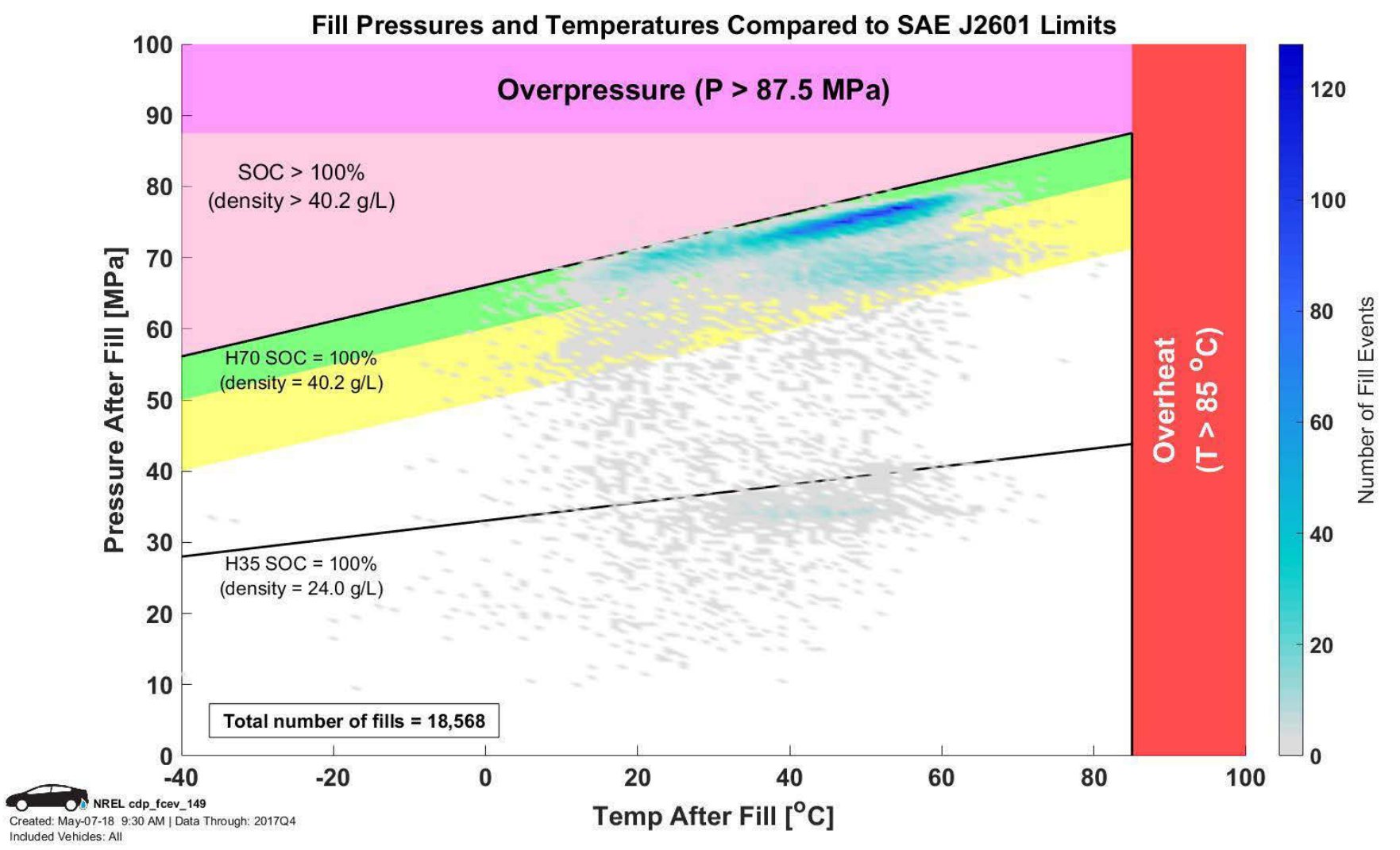


Hydrogen Performance 


\section{CDP-FCEV-129: Vehicle Tank Temperatures: Before and After a Fill}

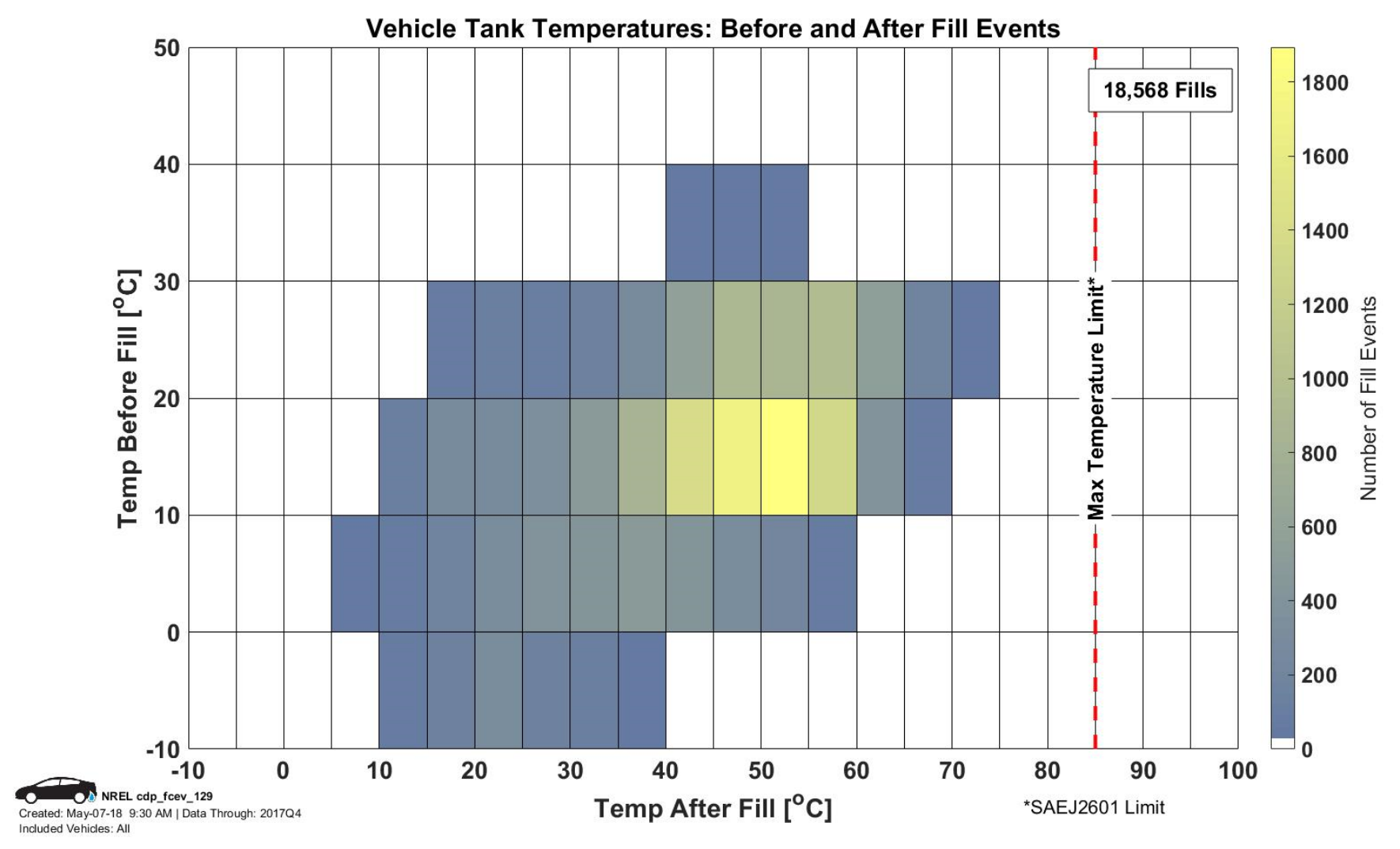




\section{CDP-FCEV-130: Vehicle Tank Temperatures and Pressures after Fill Events}

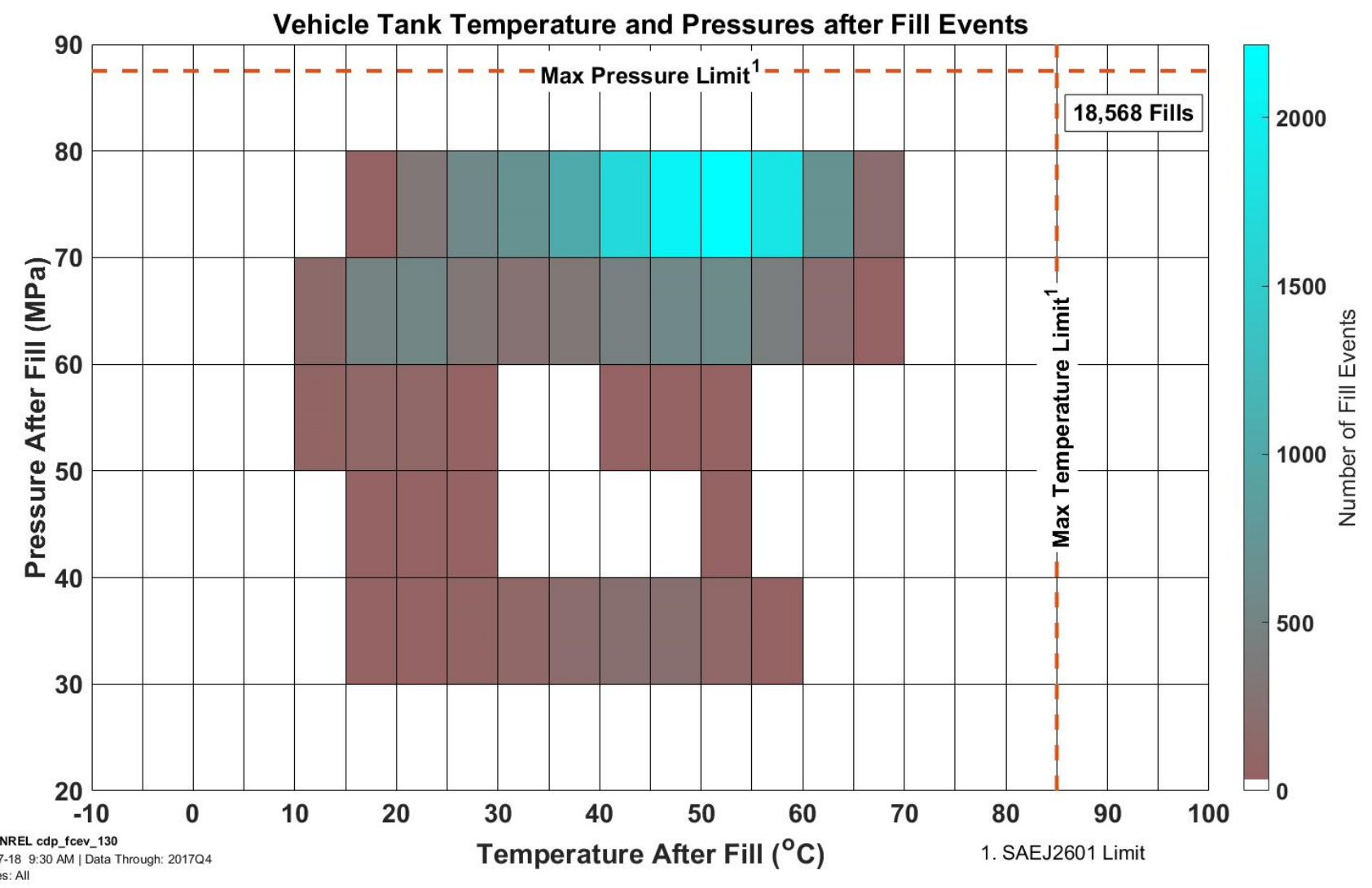




\title{
Thank you
}

\section{www.nrel.gov}

\author{
NREL/PR-5400-71643
}

This work was authored by Alliance for Sustainable Energy, LLC, the manager and operator of the National Renewable Energy Laboratory for the U.S. Department of Energy (DOE) under Contract No. DE-AC36-08GO28308. Funding provided by U.S. Department of Energy Office of Energy Efficiency and Renewable Energy Fuel Cell Technologies Office. The views expressed in the article do not necessarily represent the views of the DOE or the U.S. Government. The U.S. Government retains and the publisher, by accepting the article for publication, acknowledges that the U.S. Government retains a nonexclusive, paid-up, irrevocable, worldwide license to publish or reproduce the published form of this work, or allow others to do so, for U.S. Government purposes.

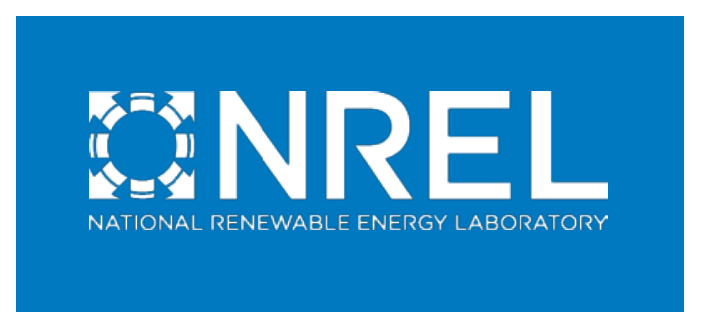

